\title{
人工高分子材料の移植と气の生体反応
}

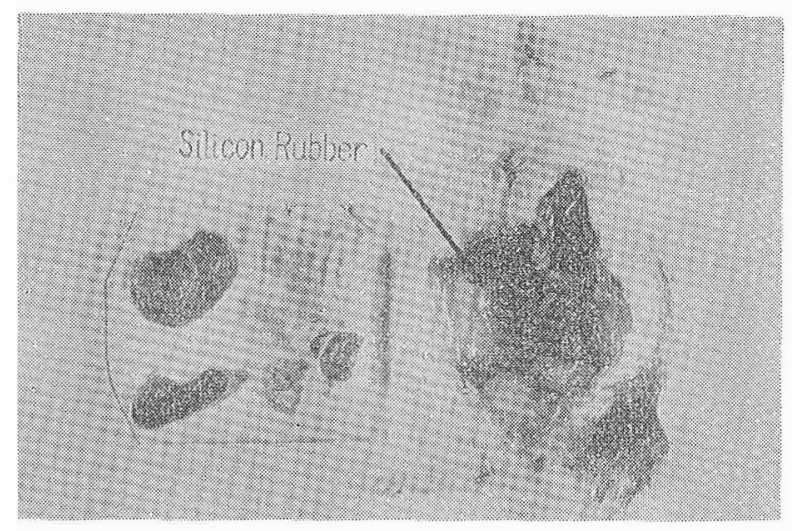

渥 美 和 彥*·渥美英子**

\section{1. 臟器移植と合成高分子}

生体内の各器官の機能特性, 各組織の代謝機構および それらの全体の homeostasis の中での相関関係の研究, 抗生物質を中心とした治療薬, 予防薬の飽くことなき研 究の進歩は, 人類における疾病の発展を拒みつつあり, やがて将来において, 結核, 脳出血, ガンさえも征服さ れ，究極に残る疾患としては，先天性の奇形，事故によ る器官の損傷および老年性変化による自然疲労の三つの 群のみが考えられるにすぎないと思われる。

そこで, 必要に応じ,これら病的器官または組織を除 去し, 新しく他の器官組織を移植したり, または人工物 の代用器官にて置換するという切実な問題が生じてく る。

機能を失った組織を, 別の新しい組織の移植によって, 機能の回復をはからうとする試みは古い昔からなされて いるが, 免疫学, 血清学の発達により, 移植の問題が基 礎的汧究され始めたのは 1920 年ごろからである。

美容整形のための皮膚移植，ホルモン機能を失った内 分泌器官の移植, 視力を失った角膜の移植, 知覚および 運動麻盘回復のための神経の移植, その他腎臟, 血管など の移植が行なわれたが，それらの広範な研究成果から， 自己の組織を自己の組織に移植する（たとえば自分の足 の皮膚を自分の手の皮膚欠損部に移植する）自己移植 autotransplantation が最も成功しやすく，ついで同じ 種属の動物どうしの同種移植 homotransplantation が 成功する可能性があり，種属の異なる動物の閒のいわゆ る異種移植 heterotransplantation は困難とされてい る。

.移植不成功の要因として, 移植器官の神経が切断され, 移植器官の神経調整がなくなったりすることの他に, た と六同種の動物の閒の組織移植でも，ちょうど血液型の
ごとく，組織と組織の閒にも型があり，それがいわゆる 抗原抗体反応を起すためであろらと推定されている。そ の前提の下に, 抗体を産生する場所である生体の細網内 皮組織を破壊する目的で, 全身にレントゲン照射を行な ったり，コルチゾンを注射したり，トリパンブリューと いら色素で機械的にブロックしたり，諸々の方法が試み られたが,すずて失敗に終っている。

そこで, 現在まで移植の成功している組織は, 軟骨や 眼の角膜のように, 解剖学的に初めから血管を欠き, 血 液循環がなくても周囲からの細胞内外液の栄養によって 生存しうる組織にのみ限られている。

生きた組織をそのまま移植することが行きづまってい る以上, むしろ何か他の人工物で, 寸なわち抗原性のな 、無生物で, その器官の機能を代行させたらという新し 、着想がこの十数年の間に撎頭してきたが，その着想に 大いに希望を持たせたのが，合成高分子の発明とその進 展であり，そのきっがとなったのが，人間の動脈の代 用に，アルコールら゙けの動物の動脈をつないで成功した 東大木本教授の研究である。

さて, 生体内に初めて使用された合成高分子は, Methyl metacrylate である。1945 年, Beck は, 頭蓋の 骨の欠損部に, Methyl metacrylate を用いて充てんし， 1947 年, Hufnagel は, やほり Methyl metacrylate で大動脈弁をつくり，胸部大動脈に挿入し，心蔵の弁の 代用を試みた。

1950年ごろより合成繊維の発達とともに, Vinyon “N”, Nylon, Orlon, Dacron, Teflon などの優秀な合成高分 子材料が世に現われ，それらが Blakemore, Hufnagel, De Bakey, Cooley, Creech らにより代用血管として使 用され，血管外科の領域は飛躍的な発展を遂げた。

一方, Lillehei, Donald, Kirklin, Lewis らとょり, 心臓の中隔欠損部のプロテーゼとして，Formalinized 
Polyvinylalcohol sponge(Ivalon) が使用されてきたが， Ivalon の用途は広く, Shumway は代用血管, 気管に, Gale は肺切後の充てん剂として, Pesek は横隔膜へル ニヤの補強材料に, Jones は肝臟損傷部の止血修復に使 用することなど，種々の用途に利用されている。

また Durham は “Abdominal pack” としての腹膜 の代用に Polyethylen を用い, Egdahl らは Silicone rubber を代用血管に使用している。

新しい試みとして, Riegler は手術創部々合成高分子 粉末 (Aeroplast) を吹きつけて，ガーゼで抒おうこと なく創傷庇護を試みている。さらに最近になり，Kolff らは Polyurethne rubber にて心臟の弁を作成し, Mandarino, Salvatore $ら は$ Polyurethne polymer (foam) を骨折の欠損部に充てんし，人工骨の代用を試みてい る。

以上, 生体内に直接に内臟する用途について述べた が，生体と直接学るい性間接に接触する人工内臟の分野 には，合成高分子の占める位置はさらに大きい。たとえ ば, 気泡型人工肺の消泡剤として Antifoam A, 膜型人 工肺の透析膜に Teflon 膜, Polyethylene 膜, 人工心臟 のポンプとして血液破壊の少ない Silicone rubber, 人工 腎臟, 人工肝臓の透析膜にゲル状 Cellphane, 血液導管と して Silicone rubber, Nylon, Polyvinylchloride, 採血 ビンに Polyethylene, さらに人工肝臟の Reacter とし てイオン交換樹脂など枚挙にいとまがないほどである。

\section{2. 合成高分子材料の生体反応}

合成高分子材料の生体組織に 対する反応は, Orlon, Nylon, Dacron, Teflon などの代用血管について, Harrison, Creech らにより広範に研究されているが, 主と して移植局所の組織反応に限られている。

Usher などを腹腔内に入れて，腸管との療着状態について調べ て抢り，Meijler らは血液導管として Polyvinyl chloride を使用すると心臟収縮力の低下を起卞伦険がある と忠告を登しているが，これら材料が，肝臟，腎臟，脾 臟, その他全身の生体臟器に与える影響についての検索 はきわめて少ないようである。

Turner が ラッテに Bakelite を移植した際, 偶然に 悪性腫瘍を発見して以来, 多くの研究者が, ラッテおよび マウスに怙ける合成高分子材料の発ガン性を報告してい る。Oppenheimerらは, マウスの皮下に諸種の合成高分 子材料を移植して検討し, Methylmethacrylate, Polyethylene, Cellophane, Saran, Polyvinylchloride, Nylon, Dacron, Orlon, Teflon, Ivalon のすべてに悪性 腫場発生の危険性があると主張している。Hueper は, Polyvinylpyrrolidone, Dextran, Ethylcellulose, Polyethylene, Polyurethane, Polydimethylsiloxane(latex),
Polydimethyl siloxane rubber などの移植により,や はりそれらに，発ガン性があることを報告している。 Hueper は, 第 1 表のように, 発ガン性高分子物質をあ げているが, これに反対する学者もあり, 今後, 慎重に 検討を重ねねばならない問題である。

また，合成高分子のアレルギー反応ないし過敏性に関 しては, Nylon, Ivalon, Silicon, などに, その存在が報 告されており，それらの製造工場にて，特異体質の患者 に，喘息様発作，尌麻疹の発生がみられるといわれ，製 品の使用について公笔衛生学的な検討も必要と考えられ る。

それらの生体反応の原因について, monomer 自体, 拉よび加工過程に残る加硫剤, 可塑刘, 安定剤, 補強剤 などに分けて各個に詳しく行なった研究は文献上全くみ られない。

また,これら高分子そのものによる抗体の発生，あるい は周囲組織の刺激による不完全抗体の発生の可能性もあ る。それらの点について著者らは詳細に検討を試みた。

生体反応を検討する方法に, 病理組織学的方法と, 血 液または組織液中のある成分の変動を測定する生化学的 方法がある。

前者には, さらに細胞形態学的方法と, 組織化学的方 法 (Alcian-blue および periodic acid-schiff の試薬に より，酸性および中性の mucopolysaccharides の変動 をみ，それにより間接的に肉芽組織の増殖状態をみる方 法）とがある。後者については, 生体反応の指標となる 物質はまだ確認されていないが，著者らは，一種の異物 反応である生体反応と細網内皮組織の機能との間には, 相関関係があり, 細網内皮組織の活動時には, 血清タン パク中の $\gamma$-グロブリン分画 (以後 $\gamma$-Gl と省略) が増加 することから，血清中の $\gamma$-G1 の変動を生体反応の一指 標として検討を試みた。

最近に至り，生体の血㳊中に properdin system とい われる自然免疫抗体様の作用物質が発見され, その測定 法も研究されているので, 将来 properdin system は生 体反応の重要な指標になると思われる。

\section{2-1. 著者らの成績}

著者らは, Nylon, Tetoron, Ivalon, Silicone rubber, Cellophane などの合成高分子材料を，マウスの側腹部 皮下に無菌的に移植し, 術後 $3 \sim 5$ カ月にわたり, 血清 タンパク質の変動, 抗体の検出, および局所組織, 肝臟, 㱟臟, 脾藏の組織について病理組織学的検討を行なっ た。

マウスは DD 系 700 頭を使用し, 側腹部を切開し縫 合のみを行なった群を対照とした。

\section{2-1-1. 血清 $\boldsymbol{\gamma}$-G1 の変動}

第 1 図のごとく，合成高分子材料の移植群はともに， 対照に比し, $\gamma-\mathrm{Gl}$ が術後 1 週ごろより急速に増加し, 1 
第 1 表

Carcinogenic Macromolecular Carbon and Silicone Polymers

Name Deseription Investigators

I. Water- Insoluble Polymers

(a) Hydrocarbon Polymers Synthetic

Polythene Polyethylene

Oppenheimer et al, Druckrey et al, Bering \& Handler

Lucite

Polymethylmethacrylate

Oppenheimer et al, Laskin et al, Zollinger

Polystyrol

Polyvinylbenzol

Ivalon

Cross linked Polyvinyl alcohol

Dacron

Polyester condensate of terephthalate \& ethylene glycol

Bakelite Phenol-formaldehyde

Oppenheimer et al, Oppenheimer et al,

Oppenheimer et al,

Turner condensate

(b) Halogenated Hydrocarbon Polmers (Synthetic)

Saran PVC, Igelit,

Vestolit,

.Vinnol

Teflon

Plioflom

Vinyon $\mathrm{N}$, Dynel

Polyvinyl chloride Polyfluor (chlor) -oleffine

Polymethylmethacrylate chloride

Copolymer of vinyl chloride Oppenheimer et al, and acrylonitrile

(c) Aminized Hydrocarbon Polymers (Polyamides)

Nylon

Polyhexamethylene diamine adipanide

Perlon

Poly- $\varepsilon$-caprolactam, polyurethane

Oppenheimer et al,

Druckrey et al,

(d) Hydrocarbon Polymers (Semisynthetic \& Natural)

Rubber

Processed latex gum

Cellophane

Processed polyglucose (cellulose)

Linen

Parchment Processed cellulose paper

Silk

Keratin

Ivory

Silastic

(e) Silicone Polymers

Polydimethylsiloxane processed (silicone rubber)

Druckrey et al,

Mecke

Oppenheimer et al,

Druckrey et al,

Körbler \& Frank

Oppenheimer et al,

Oppenheimer et al, Oppenheimer et al, Nothdurft

\section{Water-Soluble Polymers}

PVP

Polyvinylpyrrolidone

CMC, Collocel Carboxymethylcellulose Tween 60

Polyoxyethylene sorbitan monostearate

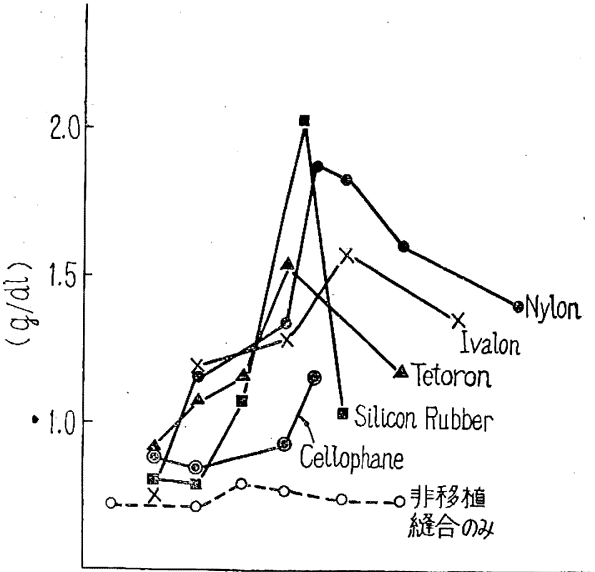

術 術

前 後

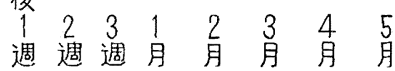

第 1 図 合成高分子材料移植と $\gamma$-Globulin (マウス実験例)

カ月にて最高值を示し，以後減少し始めるが， 3〜5 カ月に至るも, 術前に比し著しい増加を示 した。各材料別に比較検討すると， $\gamma-\mathrm{G} 1$ の増 加率の最も高いのは, Silicone rubber であり, ついで Nylon, Ivalon, Tetoron の順で, Cellophane のそれは比較的低かった。

\section{2-1-2. 抗体の検出}

検索に用いた合成高分子材料は，水および通 常の有機溶媒に溶解せず，したがって in vitro にて抗原抗体反応の実施は不可能である。そこ で in vivoにて anaphylactic shock の発現 の有無により，抗体の検索に努めた。すなわち r-G1 の增加安確かめた後, 移植片を除去し, そ の材料と同じもので粉末にし，募沸により無菌 化したものを腹腔内に注入して, anaphylactic shock を起さ叫てみた。通常の雑系のマウス は, anaphylactic shock を起しにくいので, ことに anaphylactic shockを起しやすい C.F.W. 株のマウス 30 頭を使用したが, 反応は なく, in vivo にては抗体の検索は陰性であっ た。

\section{2-1-3 病理組織学的所見}

合成高分子材料を移植した局所では，移植片 の周囲加々と内部に向って，結合組織の増殖 が認められるが，この所見は porosity にきわ めて泣しいあるいは全く欠く Silicone rubber やCellophane に拉いては認められなかった。 対照群をも含めた全例において，小膿瘍形成な いし化膿性炎症像の認められなかったことは, 本実験が無菌的に行なわれ，したがって $\gamma-\mathrm{Gl}$ 


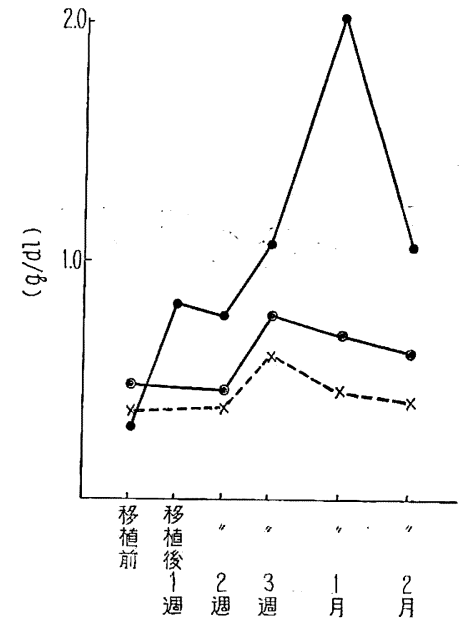

- - Silicone rubber (安息香酸残留)

-○- Silicone rubber (安息香酸完全取去)

ーメー 移植せず縫合のみ（対照群）

第 2 図 Silicone rubber 移植後の $\gamma$-Globulinの変動

の増加は細菌感染と関係がなく，生体反応そのものの結 果であると断定してよいと思われる。なお，肝臓，脾臟 などの細網内皮組織に，生体反応の結果と思われる増殖 像が移植後 2 3 週以後に現われる傾向が認められた。 しかし少数例の例外をあり, さらに今後, 検討を要する ものと思われる。

\section{2-1-4. 加硫剤, 安定剂などの影響}

non- wetable で比較的反応が少ないと思われた Silicone rubber (KX 4892)が予想に反して生体反応が強く でたので，製品について検討を行なったところ，加硫中 に残留する安息香酸の影響とわかり，完全な熱処理によ り安息香酸を全く除去した KX 4892 を移植したところ 第 2 図のごとく, $\gamma$-G1 の增加率は低くなった。さらに, Silicone の monomer おょよび带鉛粉末などを入れたのみ で加硫以前のものを，マウスに移植し，比較検討中であ る。

天然ゴムについても，その副作用はゴムそのものより も, latex 中に含有される不純タンパクと, 加硫に用い
るイオウによるものと思われる。そこで透析によりタン パク質を完全に除去した latex を $\gamma$ 線にて加硫を行な ったゴムをマウスに移植し，その生体反応を検討中であ る。

\section{3. 医学における合成高分子の将来}

Skales らは，生体組織に内臟する理想的合成高分子 の備えるべき性質として，i）生体の組織液によって modyfy されない。ii) 化学的に inert である。iii) 周 囲に炎症を起さず，加異物反応がない。iv）発ガン性 がない。v）アレルギー反応ないし過敏性がない。vi）組 織内に長期間さらされても，抗張力，弾性などの機械的 能力を失わない。vii）加工造型が簡易で，かつ廉価であ る。viii）消毒中に変性しない。

などの諸点をあげているが，これは，とりもなおさず 人工高分子が生体高分子に近づくことである。しかし， 人工高分子が生体高分子と全く同質のものに近づきえて も，新陳代謝を行ないらる細胞組織でない限り，劣化と いら点においてな护限界があるように思われる。

そこで，酸素，炭酸ガスなどをエネルギーの基盤とし て新陳代謝を行なら生きた人工高分子の出現を期待した いのであるが，それは，果して夢であろらか。

アミノ酸から核酸, ポリペプチドの合成に成功して以 来, 科学者の関心は, タンパク質合成，さらに生体タン パク質の合成に向けられて㧍り，形態にとらわれずその 機能の完全なる代行を目的とする人工内藏の発展は, こ れらの研究と手を携えて, 生体の神秘の屝を一枚一枚開 けつつ㟧る。そして，生命の起原への道は，末だな扔遠 しといえぞも，必ずしも不可能ではない時代に，一歩一 歩近づきつつある。

ご指導ご校閲を賜った木本誠二教授に梁甚なる感謝を 捧げるとともに，ご指導ご嗳助をいただいた高分子学分 常務理事荒井溪吉氏，東洋レーヨン荒井貞夫氏，信越化 学藤田桂夫, 宮坂勝郎両氏, 天然ゴム研究所国沢新太郎 氏，日清紡績声田包義氏，新潟化工小川辛一氏に深〈感 謝する。(*東京大学医学部木本外科教室, **東京女子医 大細菌学教室)

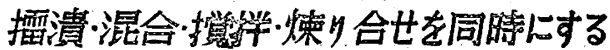

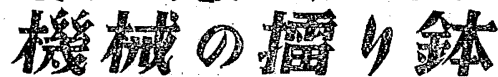

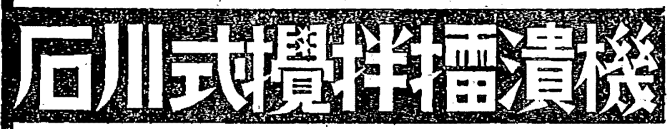

新製品

、分析用瑪璔邓はジンターコルンド

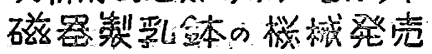

擂鍊の直径 10 玈位より 1 米位まで 大小加熱用等数百種製作

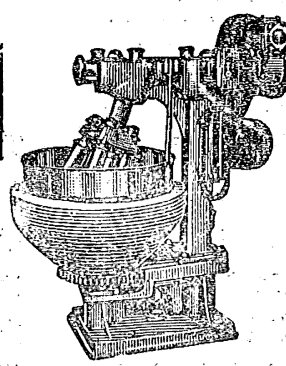

警㱸

東京都港区芝三田四国町 2 番地 2 号 電話三田(451) 3918 1 8492 